\title{
Socioenvironmental impacts of dam in the Jari Valley, Amapa, Brazil: community perceptions
}

\author{
Maíria de Sousa Lopes \\ Daguinete Maria Chaves Brito
}

${ }^{I}$ The Environment Secretariat in State of Amapá, Macapá, AP, Brazil

"I Federal University of Amapá, Macapá, AP, Brazil.

\begin{abstract}
The expansion of the Brazilian electricity sector is based on the construction of new dams. However, dams generate impacts, especially on riverine communities. Thus, this paper examined the local communities perceptions about the socioeconomic and environmental impacts of the Santo Antônio do Jari Dam, in Amapá. Data were obtained through surveys using the snowball sampling method. To analyze the perception data the Bardin's analysis of content was used. The research showed that, before the construction of the dam, there was a very intimate bond between the communities, the environment and the nature, which influenced the communities perceptions mainly regarding environmental impacts, relocation, changes in livelihood and access to natural resources.
\end{abstract}

Keywords: Riverine communities, Santo Antônio do Jari, Socioenvironmental changes.

São Paulo. Vol. 24, 2021

Original Article

DOI: http://dx.doi.org/10.1590/1809-4422asoc20190068r3vu2021L2AO 


\section{Introduction}

With the growing demand for energy and government interest in large public enterprises, the construction of hydroelectric power plants (HPPs) reached its peak by the end of the 20th century (TULLOS; TILT; LIERMANN, 2009; CASTELLO; MACEDO, 2016). The demand for electricity aroused Brazil's interest in the expansion of its generating park, prioritizing the building of large HPPs in the country (MME, 2007). State and Brazilian energy sector data indicate that the country intends to add about $2.8 \mathrm{GW} /$ year of hydroelectricity by 2027 (MME; PDE, 2019), with the North region and the state of Paraná being the focus of this expansion.

Brazil is known as one of the largest producers of energy from hydroelectric sources, due to the privileged territory and its rivers with enough flow to produce electricity (CARVALHO, 2003; DERROSSO; ICHIKAWA, 2014; IEA, 2017).

HPPs have played a key role in meeting purposes such as water and energy demand, flood control and irrigation (MANATUNGE; NAKAYAMA; PRIYADARSHANA, 2008; YANKSON et al., 2016). However, the construction of HPPs is one of the anthropic actions that most negatively affect nature and society. Despite being recognized as renewable energy sources, they are responsible for flooding areas of native forest; diversion and alteration of river courses; habitat loss, among other impacts on the ecosystem and biodiversity (SOITO; FREITAS, 2011; FONSECA, 2013; FEARNSIDE, 2015).

Richter et al. (2010) highlight that the benefits of HPPs are usually delivered to urban centers or agricultural developments on an industrial scale, so river-dependent populations commonly experience disturbances in their livelihoods, loss of food security and other impacts on their cultural, spiritual, and physical activities. Although HPPs provide benefits to society, such as the energy supply itself, adverse impacts are much more common and typically outweigh the benefits for downstream populations, resulting in reduced incomes and livelihoods.

The Amapá, a Brazilian state located on the left bank of the Amazon River, in the so-called eastern Amazon, has four HPPs in its territory: Coaracy Nunes, Cachoeira Caldeirão, Ferreira Gomes and Santo Antônio do Jari (UHESAJ), on the border of Amapá and Pará. Together, they produce approximately $922 \mathrm{MW}$ and are fundamental to the interconnection of the energy production matrix of Amapá to the National Interconnected System (SILVA; LIMA; SILVA, 2016).

The implementation of HPPs in Amapá, as well as other hydroelectric plants in the country, contributes to changes and reordering in the urban and rural centers of the municipalities affected by them, bringing environmental and socioeconomic repercussions.

In the context of the progressive development of Amapá, the implementation of the UHESAJ, in May 2014, is a modifying enterprise of natural areas causing environmental, social and economic impacts. Thus, it is imperative to understand how the transformations of the environment have affected society, the landscape and the environment, since the socio-environmental studies of HPPs on communities are still incipient, especially about the Jari Valley. 
This research seeks to identify and analyze the perceptions of local actors affected by the UHESAJ, in the Jari Valley, State of Amapá. To this end, we assume that impacts provided by the implementation and operation of the UHESAJ led to significant negative changes in the socio-environmental conditions of the communities, producing consistent changes in the way income is obtained, pre-existing economic activities and local environmental and social characteristics.

\section{Methodology}

\section{Study Area}

The study area comprises four (4) communities of the municipality Laranjal do Jari (AP), directly affected by the UHESAJ: São Francisco do Iratapuru or Iratapuru (upstream of the dam), Santo Antônio da Cachoeira or Cachoeira, São José and Padaria (located downstream of the dam).

These riverine communities have their livelihoods based on extractivism, especially the Amazon nut (Bertholletia excelsa Bonpl), subsistence agriculture and fishing for family support (ECOLOGY BRASIL, 2009b, OLIVEIRA, 2012).

The communities are settled in the area known as Jari Valley, characterized by the presence of primary rainforest, rich in forest resources, such as Amazon nut, açaí (Euterpe oleracea Mart.), white pitch "breu branco" (Protium pallidum Cuatrec), copaíba (Copaifera duckei Dwyer) and andiroba (Carapa guianensis Aubl.) - sources of exploitation of extractive populations and important resources for the regional economy (OLIVEIRA, 2012; GREISSING, 2010).

The UHESAJ is located on the Jari River, on the border of the states of Amapá and Pará, in the territory of the municipalities of Laranjal do Jari (AP) and Almeirim (PA) (Figure 1). The UHESAJ operates as a run-of-river reservoir and has a $31.7 \mathrm{~km}$ long lake with installed capacity of 373 MW (CESBE, 2018; ECOLOGY BRASIL, 2009b). 
Figure 1 - Location of the UHESAJ and spatial disposition of the communities
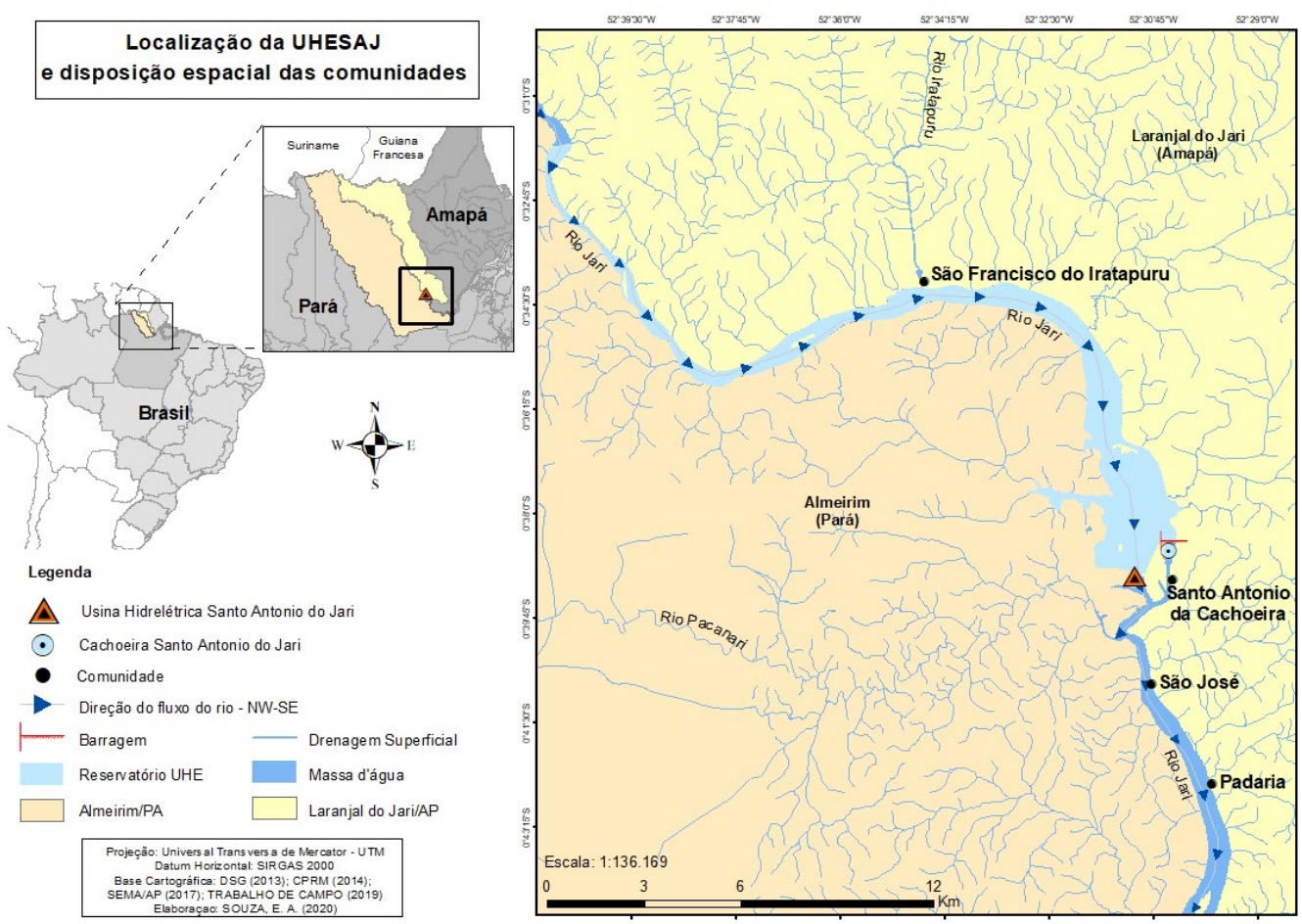

Source: Souza (2020).

\section{Socioeconomic characteristics of respondents}

The occupations of the 42 respondents (26 men and 16 women) comprise mainly extractivism, family farming and housework. The age ranged from 21 to 76, with a long time of residence with an average of approximately 36 years, confirming the considerable participation of people living for several years in the Jari Valley, who proved to be profoundly aware of the reality of the communities studied before and after the construction of the HPP.

\section{Data collection}

For data collection, field work was carried out between July and November 2018, by participant observation (GIL, 2008; MARTINS; THEÓPHILO, 2009), conducting interviews and documentary analysis.

During our stay in the communities, participant observation allowed us to understand the socio-environmental context, in its physical, economic and social aspects to which residents live and the relationships between people and the new environment reconfigured after the implementation of the hydroelectric plant. We also conducted 42 
(forty-two) semi-structured individual interviews with open and multiple choice questions with the residents of the Iratapuru, Cachoeira, São José and Padaria communities, addressing the following aspects: expectations related to the presence of the HPP in the region, environmental and socioeconomic impacts, in addition to the status of access to natural resources, observed by the communities after the implementation of the UHESAJ.

The members of the communities to be interviewed were selected in collaboration with community leaders, using the snowball selection method, according to Baldin and Munhoz (2011), where early study participants indicate new participants who in turn indicate new participants and so on, until the proposed goal is achieved. With this method, the saturation of information occurs when new interviewees start to repeat the contents already obtained in previous interviews, without adding new information relevant to the research.

To be considered a participant, the respondent should preferably be a resident of the communities studied, head of family or family guardian and over 18 years old.

To identify the main impacts resulting from the implementation of the UHESAJ for the area, information was also compiled from the analysis of documents such as the Environmental Impact Study (Estudo de Impacto Ambiental - EIA), Basic Environmental Project (Projeto Básico Ambiental - PBA), Environmental Impact Report (Relatório de Impacto Ambiental - RIMA) and monitoring reports of the UHESAJ (ECOLOGY BRASIL, 2009 a, b, c), which contributed to the data analysis.

\section{Data analysis}

The Bardin content analysis (2010) was used to analyze the perception of affected communities. This methodology aims at the analysis of communication objectively, by which reliable inferences of data and information are sought, from written or oral speeches, enabling more efficient exploration of the declaration of social actors (SILVA; GOBBI; SIMÃO, 2005; MARTINS; THEOPHILO, 2009).

The interviews were transcribed and analyzed by themes, which were being coded as they emerged during the field investigation. Initially, a prior analysis of the material for organization was performed, followed by exploratory analysis - stage of the codifications and classifications of the materials and, finally, the interpretation of the collected data. The selection of themes and criteria is based on different data sources and information from the existing literature on the impacts of hydroelectric power plants (BERMAN, 2007; FEARNSIDE, 1999, 2015; SOITO; FREITAS, 2011; SICILIANO et al., 2015; YANKSON et al., 2016, SICILIANO; URBAN, 2017). The criteria used are shown in Table 1.

A relative frequency analysis of these themes was also performed as the sum of the answers given to a certain theme on the sum of all the items answered, to list the themes related to the impacts of the HPP, which occur more frequently in the interviews. 


\section{Results and discussion}

In this section, we present the expectations with the arrival of the hydroelectric plant, the effects of the UHESAJ on socioeconomic activities, environment and access to natural resources. For the purpose of analysis, the perceptions are organized in a summary table and, when necessary, this summary is complemented with the transcription of excerpts of statements.

\section{Expectations}

The general analysis indicates that the communities had expectations related to the improvement of quality of life, in the sense of providing services such as quality water and energy, sanitation and sewage system and job opportunities. These expectations were created due to the signing of the understanding protocol, in which the company Jari Energética S.A. committed to relocating and building houses for the communities Cachoeira and Iratapuru, with the supply of 24-hour energy, water treatment, among other commitments contained in the impact mitigation programs (ECOLOGY BRASIL, $2009 \mathrm{a}, \mathrm{b}$ ).

However, when asked about meeting expectations, $90 \%$ of the respondents answered negatively because the commitments made in the understanding protocol were not fully executed, generating dissatisfaction and conflicts between the communities and the consortium responsible for the HPP. The community reported the dissatisfaction of seeing the "linhão de Tucuruî", which transmits the energy generated by the UHESAJ to the capital and other regions of the country, crossing the communities without them, the main affected, having access to electricity. The statement below expresses this dissatisfaction:

They said there was going to be power from this dam, but there isn't. If it wasn't for this old engine here that Jari gave us, our life would be worse. The power grid goes over our head, but the power doesn't get here (50-year-old man from Cachoeira).

\section{Analysis of impacts from the perspective of affected communities}

The perception of the interviewees points to the formation of the reservoir as one of the main effects of the presence of the UHESAJ in the region, bringing changes such as the elevation of the river level, alteration of water quality, erosion of the river bank, relocation of communities, loss of species of local fauna and flora - directly influencing access to natural resources and the change in regional landscape beauty.

The changes perceived by the community were classified into two (2) main categories: socio-environmental impacts and on access to natural resources. Table 1 shows the result of the categorization of the data, where the categories, the criteria used, the impacts mentioned by the local actors and the frequency that the impacts occur in the interviews are displayed.

\section{Socio-environmental impacts}


The main records of social impacts were loss of leisure areas, conflict with outside fishermen, relocation of the community and decrease in income (Table 1). The most reported impact concerns the loss of areas used for leisure. With the formation of the reservoir, the waterfalls and beaches were submerged, the waterfall of Santo Antônio lost its scenic beauty and the leisure activities nearby were impaired.

The Rivers Jari and Iratapuru have great importance for the members of the four communities studied since they have waterfalls and beaches along their course used for a family fun time. (ECOLOGY BRASIL, 2009b; LEITE, et. al., 2015; CAMPOS, 2016). The leisure activities practiced by the riverine population are related to the elements of nature such as river baths, waterfall walks, boat rides and recreational fishing - considered a social event by the communities.

All these practices represent important events to preserve their memories and memories of the place, especially the waterfall of Santo Antônio. The longing in this report demonstrate this:

A lot of beautiful waterfalls dried. There was a waterfall that I thought was very beautiful. I liked that waterfall very much (53-year-old man from Padaria).

It was very beautiful here. There was a waterfall, an island here, another over there and the "lajeiro". We had barbecue and bathed there. It was very beautiful. All this is over, where it was our place, where my father taught me how to fish (45-year-old woman from Iratapuru).

There was also mention of conflicts with commercial fishermen from outside the region coming to fish in the vicinity of the communities and inside the Iratapuru River Sustainable Development Reserve (SDR), using predatory and forbidden fishing gear, such as harpoon and trawl nets. Fishing in the SDR was facilitated due to the improvement of the navigability conditions of the Iratapuru River - resulting from the filling of the UHESAJ reservoir - promoting access to reserve borders. These conflicts can be considered secondary to the implementation of the UHESAJ in the region, however it is emphasized that indiscriminate fishing competes directly with the family fishing, which is simpler and rudimentary, of communities generating serious conflicts, as illustrated in the report below:

Many fishermen come here from Laranjal to hunt and fish and sell in the city. They don't respect spawning, they take the big fish, and the small ones they don't bother to leave them in the river. We (from here) catch the small fish and let them go because we know we're going to need them in the future (30-year-old woman from São José).

When the waterfalls dried up, we ran out of fish. The little that's left, the shellfishers from Laranja come fish and there's nothing left for us. The community has no chance of fishing anymore (64-year-old man from Padaria). 
Table 1 - Perception of local actors about the impacts of the implementation of the UHESAJ

\begin{tabular}{|c|c|c|c|c|c|c|c|c|}
\hline \multirow[t]{2}{*}{ Categories } & \multirow[t]{2}{*}{ Criteria } & \multirow[t]{2}{*}{ Impacts } & \multicolumn{4}{|c|}{ Communities } & \multirow[t]{2}{*}{ Total } & \multirow[t]{2}{*}{ Freq. $\%$} \\
\hline & & & Iratapuru & $\begin{array}{l}\text { Cacho- } \\
\text { eira }\end{array}$ & Padaria & São José & & \\
\hline \multirow{7}{*}{$\begin{array}{l}\text { Environmental } \\
\text { impacts }\end{array}$} & \multirow{7}{*}{$\begin{array}{l}\text { Changes in flora, } \\
\text { fauna, hydrology } \\
\text { and ecosystems }\end{array}$} & Death of trees & 15 & 3 & 6 & 4 & 28 & 5.6 \\
\hline & & Decrease in fish & 10 & 5 & 8 & 4 & 27 & 5.4 \\
\hline & & Riverbank erosion & 0 & 7 & 8 & 5 & 20 & 4.0 \\
\hline & & Change in scenic heritage & 3 & 2 & 10 & 3 & 18 & 3.6 \\
\hline & & Hydroelectric lake construction & 12 & 1 & 1 & 0 & 14 & 2.8 \\
\hline & & Rising river level & 12 & 1 & 0 & 0 & 13 & 2.6 \\
\hline & & Increase in mosquitoes & 3 & 0 & 1 & 2 & 6 & 1.2 \\
\hline & & Increased incidence of malaria & 2 & 0 & 0 & 0 & 2 & 0.4 \\
\hline
\end{tabular}




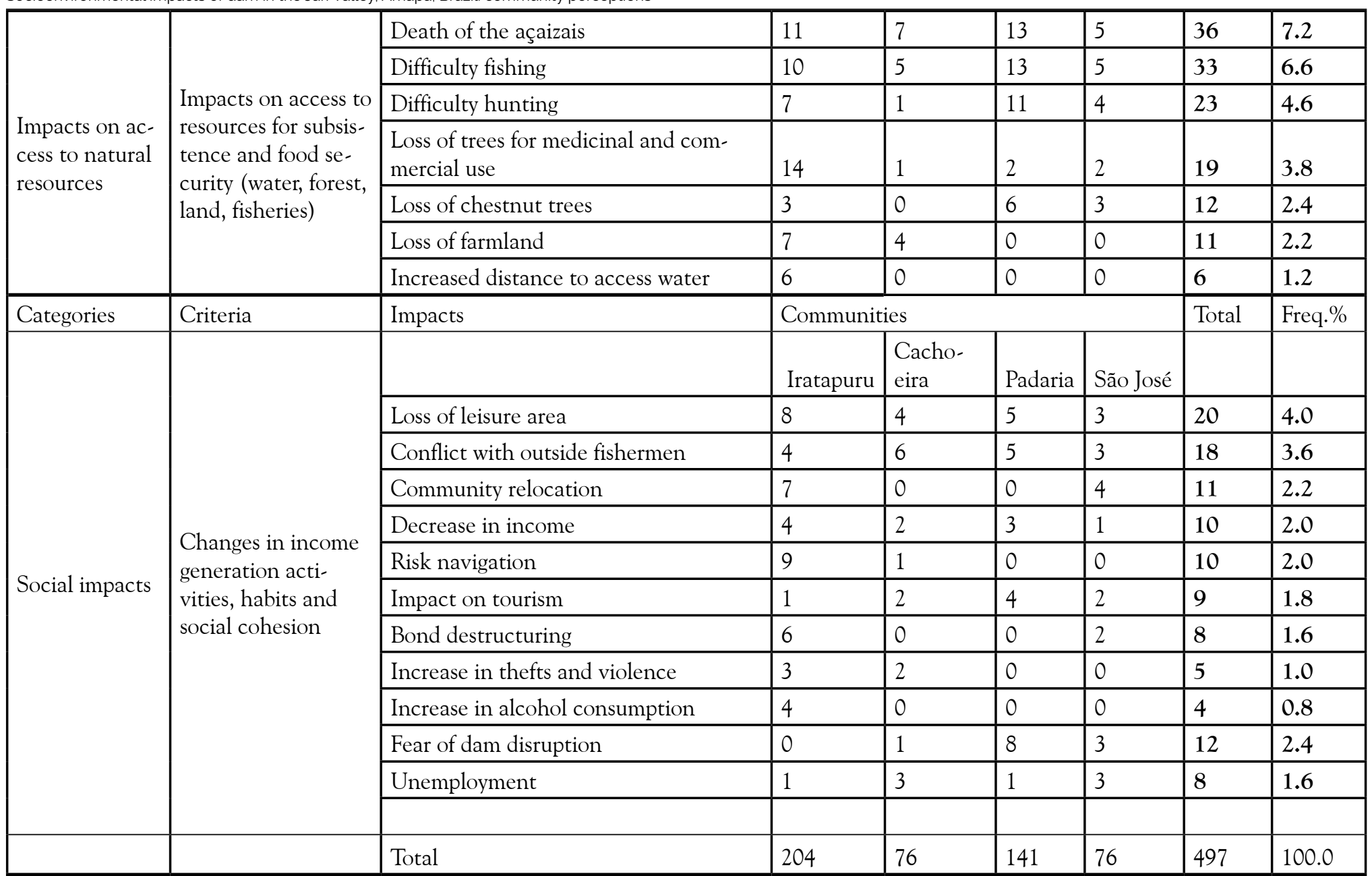

Source: Prepared by the authors, 2019. 
The EIA-RIMA of the UHESAJ shows that one of the conflicts in the region of the communities is related to the invasion of hunters, fishermen and prospectors within the SDR (ECOLOGY BRASIL, 2009b). These conflicts arise because fishermen approach in order to practice predatory fishing, an attitude considered unacceptable by residents. On the other side of the story, the fishermen, coming mainly from the headquarters of the municipality of Laranjal do Jari, argue that one of the best places for fishing is the area upstream of the Santo Antônio Waterfall and that, therefore, many venture to fish in these areas, generating disagreements with the residents of the region. It is noteworthy that the conflicts are accentuated by the lack of supervision by the responsible environmental agencies.

The implementation of the UHESAJ led to the relocation of the Cachoeira and Iratapuru communities. The first community had their houses rebuilt in an area adjacent to the previous village, in a process started in 1995 and completed in 2001. The second community was relocated to a place relatively distant from the river, totally altering the dynamics and relations of the riverine with the river and the resources of the region (ECOLOGY BRASIL, 2009 b).

Although the resettlement program has delivered new houses with sanitation network and other improvements, residents have faced problems such as multifamily occupation in houses with dimensions planned for only one family (ECOLOGY BRASIL, 2009 a), poor supply of water and energy - resulting from poorly implemented impact mitigation activities.

Bermann (2007) and Cruz e Silva (2010), state that those affected by HPPs can have their way of life impaired, since in many cases they are implemented without considering local actors, nor allow an effective participation of populations in decision-making. The residents of the Iratapuru community claim to have their way of life changed, because they had to leave their homes, on the riverbanks, which made it difficult to perform daily activities such as unloading goods, transportation of people and access to water. The excerpt below illustrates the most common statements:

My sadness is that I lived near nature and I don't anymore. Living away from the river and water got worse. There is no water in the village, so we often ran out of water even to drink. If we wanted to drink, we had to get rainwater or load, in the wagon, from the river home. Before, to have water, we only had go out the door of the house and get it (54-year-old man from Iratapuru).

Relocated families complain that they have not been informed about the relocation process and that they did not adapt to the new territory and the new way of living. Nowadays, their new houses are far from the river, causing a rupture of the strong relationship between the riverine and the waters - the guiding thread of their daily activities. Campos, Mendonça and Campos (2018), studying the impacts of the UHESAJ on the Iratapuru community, highlight that the relocation of these families not only represented a change in the physical and structural space, but also altered the perception of residents 
regarding the relations with nature and the new environment with which they have no identity, nor a feeling of belonging.

Studies on the theme of hydroelectric power plants show that HPPs are implemented in social spaces created by and for riverine populations to produce their livelihoods through agriculture and fishing. Thus, the construction of HPPs occupy spaces of sociocultural reproduction and end up generating conflicts whose essence, for some, is the appropriation of geographic space as a form of specific merchandise for the generation of hydroelectric power; and, for others, the social use of sociocultural reproduction as a way of life (BERMANN, 2007). Therefore, the relocation of populations, the loss of living areas, the fear of dam disruption and the modification of the landscape impose important changes in the daily life and territory of the affected communities (CRUZ; SILVA, 2010; BORGES, SILVA, 2011). At the end of this process, what remains is the deprivation of the territory and the memories lived in the old one.

Bermann (2007) and Koifman (2001) stress that the construction of an HPP represents, for the affected populations, the destruction of their life projects, determining the removal of their lands without presenting compensations that can, indeed, ensure the maintenance of their reproductive conditions at the same level as that found before the implementation of the enterprise.

The environmental impacts are related to transformations in the physical environment, especially the river, the Santo Antônio waterfall and forests. The most striking changes relate to the decrease and death of fish, death of trees, changes in water quality, erosion of the riverbank, deforestation and alteration of scenic heritage (Table 1). The latter is directly associated with the presence of the Santo Antônio waterfall and the natural elements that surround it (ECOLOGY BRASIL, 2009c).

These impacts are marked in the memory of the community because they arose during the period of preparation of the land for the physical facilities of the HPP, including the river damming. In this phase, the changes in the physical aspects of the environment modify the natural configurations due to the use of machinery and equipment to deforest the area and form the reservoir, affecting the morphology of the riverbed and the species composition of riverine areas (ECOLOGY BRASIL, 2009c; TULLOS; TILT, LIERMANN, 2009).

Following this reasoning, Derrosso and Ichikawa, (2014) reinforce that it is at the time of the construction of the dam that the main environmental and social problems arise. At this stage, a large extension of land, mostly productive, is flooded causing serious changes in the social and ecological system.

Fish death, a recurrent impact on HPP impact studies, is also present in the memory of riverine communities. According to them, the fish died during wildlife rescue activities. After the start of the operation, they witnessed an episode of fish death in the Jari River, around the UHESAJ, which has contributed to the reduction of the supply of fish in the region (PACHECO, 2015) and consequent change in the food patterns of the riverine. The following statement illustrates how the fish deaths occurred: 
When they open the floodgates, the fish that are trapped descend and when they close them the area dries, the water heats up and they die. This happened a lot during the works. At that time I saw a lot of dead fish buried (66-year-old woman from Iratapuru).

Some impacts were more strongly reported than others, depending on the location of the community in relation to the HPP dam, whether upstream or downstream. In the upstream Iratapuru community, the respondents predominantly cited: death of trees, decrease in fish, lake construction, increased river level and change in water quality. These impacts are commonly perceived by residents because they have had their village relocated and use the lake of the HPP for transportation, from the village to the headquarter of Laranjal do Jari, where the scenery of dead trees is accentuated.

Regarding the water quality, the changes generated by the construction of the dam and reservoir filling trigger changes in environmental characteristics whose consequences reflect changes in temperature, nutrient concentration, luminosity, particulates in suspension, among others (ECOLOGY BRASIL, 2009 b, c). These changes are reflected in the daily life of all communities, hindering access to drinking water for consumption and bringing concerns regarding the effect of river water intake for their health, as observed in the following statement:

When the trees of the lake began to die the water was stinky. It'd go down and make everything stink. After this hydroelectric plant, the water never cleaned up. In winter the water gets darker, it looks like mud. And how are we going to drink that water? (56-year-old woman from Iratapuru).

The limnological monitoring reports of the UHESAJ - dealing with the water quality of the Jari River - indicate that the parameters of water quality such as color, turbidity, presence of solids and coliforms were elevated soon after filling the reservoir in 2014, and that they remained so until the release of the 2017 reports, thus confirming the perception of residents regarding the changes in the quality of the river water (ENERGIAS DE PORTUGAL, 2017a).

Changes in water quality affect the survival rates of fish populations. The decrease in the movement of the dammed waters in the reservoir lake causes changes in temperature and dissolution of carbon dioxide and oxygen, decreasing the quality of the water and influencing the survival of fish and the health of the populations affected by the HPP that consume this resource (FEARNSIDE, 2001; AGOSTINHO; PELICICE; GOMES, 2008).

On the other hand, the communities downstream of the UHESAJ (Cachoeira, Padaria and São José) reported deforestation and erosion of the riverbank as marked impacts. Regarding deforestation, local actors reported that it had been observed in order to build the construction site and that; in addition, the region has been suffering from illegal deforestation to obtain wood and use of the area for agriculture.

As for the erosion of the riverbank, the residents of Cachoeira and São José considerably mentioned this impact. In these communities, the riverbanks present a process of degradation characterized as riverbank breaks. Erosion is attributed to the intense 
movement of vessels with loads and workers, in the construction phase, which produced small waves, contributing to the landslide of the riverbank. The statement below illustrates this situation:

The impact was so great that it wiped out the riverbank. When we "gave faith", the river was huge (41-year-old woman from Cachoeira).

During the construction of the UHESAJ, the opening of accesses, dam construction and river diversion caused acceleration of erosive processes, so that the surroundings of the HPP reservoir have areas with slight, moderate and strong susceptibility to erosion (ECOLOGY BRASIL, 2009 b).

The 2017 erosive process monitoring report points out that erosion of the downstream to the UHESAJ is due to anthropic intervention, soil texture characteristics and natural movement of river water (ENERGIAS DE PORTUGAL, 2017 b). It highlights that the evolution of erosive processes is associated with hydrological periods and that the measures taken have proved to be efficient. However, considering the report of residents of erosive resumptions, it can be said that containment measures are not having the expected effect and that it is necessary to continue monitoring in these areas.

The river's cliff fell. The cliff was much bigger, but the watercrafts went straight through full of worker and knocked everything down. They put stone to decrease the strengh of the water, but the stones fell into the river and the cliff continues to fall. It won't be long and our houses will fall into the river (21-year-old man from São José).

\section{Impacts on access to Natural Resources}

Impacts on natural resources were those that affected the quality of services offered by the environment of the region, capable of reducing the well-being of the populations living there.

Flooding of the forest led to the death of the açaizais, the loss of fertile land - used for agricultural activities - but above all represented the decrease of species of interest of hunting and fishing resources. Table 1 displays the impacts on access to natural resources.

The HPP promotes changes in ichthyofauna of interest for human consumption, decreasing the species and affecting human populations that depend on these resources for subsistence (JUNK; MELLO, 1990; AGOSTINHO; PELICICE; GOMES, 2008). It was no different with the communities studied. Community members have suffered negative effects on subsistence fishing. The reports indicate that it is increasingly difficult to catch fish for feeding, due to the decrease in the number of fish and the increase in the distance to access new fishing sites. The excerpt below demonstrates these difficulties:

In those times there was a lot of fish, we chose the fish that we were going to kill to eat. Today, if you see the first one, you kill because, if not, you don't 
eat lunch. You can only fish there at the headwaters of Iratapuru, which is too far to go. We go because we need to (45-year-old man from Padaria).

These impacts reveal a decrease in the ability to obtain fishing resources and other sources of protein, essential for maintaining the food and economic security of communities. Santos, Cunha and Cunha (2018) and Chandy et al, 2012, in similar scenarios, concluded that the impacts of the hydroelectric plant resulted in a decrease in the amount of fish, causing the increase in the social vulnerability of fishing as an economic and subsistence activity, corroborating the situation observed by the populations affected by the UHESAJ.

The death of the açaizais harmed the residents of São José and Cachoeira, who depended on the collection of the açaí, native of the region, to complement income, especially in the post-harvest period of the chestnut. The excerpt below illustrates this:

From the açaizal we took for consumption and to make money, but it's all gone. That was the first major loss we had. That was an impact they didn't make a payment to make up for. We're left with only the damage (66-year-old woman from São José).

The dynamics of economic activities took place, first with the chestnut harvest, after which the communities worked with subsistence agriculture and açaí collection and, later, with fishing to complement family income. However, with the effects of the UHESAJ this cycle was compromised, especially due to the loss of the açaizais and the decrease in fishing resources. Jericó-Daminello et al. (2016) also identified that non-timber forest products such as açaí, in addition to the use for family consumption, are important sources of income for populations affected by the Tapajós HPP.

The flooding of the region near the communities, caused by the dam, and deforestation to form the construction site also reduced access to forest resources such as andiroba, pracaxi (Pentaclethara macroloba Wild), rubber tree (Hevea brasiliensis (Willd. ex A.Juss.) Müll.Arg.), virola (Virola surinamensis (Rol. ex Rottb.) Warb.), cedar (Cedrela sp P.Browne) and chestnut trees present in the área, a direct influence of the enterprise. In addition to the ecological functions performed by these species, such as providing food for ichthyofauna, birds and mammals in the region, residents also cited uses for the construction of houses and vessels and also for medicinal and commercial purposes.

Therefore, since the implementation of the UHESAJ in the region, most changes on access to natural resources are reflected in decreasing livelihoods and reduced access to existing resources. The loss of the most fertile land in lowland soils, access to fish and hunting and the decline of açaizais affected the acquisition of food, compromising the food and economic security of communities. This reality is recognized in the statements below:

The resources of the area changed a lot. Before they were preserved, most people could get their livelihoods from the area. Today the açaizais died, the andiroba, the pracaxi and the fish decreased. Before I took between 500 and $600 \mathrm{~kg}$ of andiroba and sold to make extra money (31-year-old 
man from Iratapuru).

It was such a misleading advertisement. At the meeting, they said that the fish would continue, the trees and the açai too. But what happened was: the acai was over; the fish reduced, the forest at the site of the dam, which was the most beautiful thing, today you only see stone. Now they generate energy there and the environmental impact was too great for us. Now even eating has gotten harder (45-year-old man from Padaria).

On food safety, the narratives also describe that getting food was compromised. Before the UHESAJ was implemented, if there was a need for food they easily accessed it through hunting, fishing and agricultural products produced by them, but with the HPP and the impacts on the environment the preys disappeared as well as the fish, therefore, they had to resort to the market to supply the family with basic supplies for human survival. The excerpt below describes this scenario:

\begin{abstract}
Before you went to the river, put a net, caught a little piabinha and fed your family. But after this dam it's been a long time that we spend all day without eating, try fishing and can't, even to eat. And that happened after this dam here. In these times of crisis, you only eat if you have money to buy in the market and most of the time we don't have money (28-year-old woman from São José).
\end{abstract}

These additional expenses have negatively affected residents' livelihoods and made them increasingly dependent on the city's food supply market. This scenario was observed by Siciliano and Urban (2017) and Yankson et al. (2016), who studying dams from Africa and Asia, concluded that the reduction of forested areas for the construction of HPPs severely undermined the livelihoods of local communities and increased the cost of living. According to them, in developing countries, rural areas, which have as their core activity family agriculture, are heavily dependent on natural resources, responsible for the livelihoods of the poorest.

\title{
Considerations
}

Before the implementation of the UHESAJ, the communities studied had an intense bond with the territory and nature, particularly with the river and the forest. The perception of the community about the impacts of the UHESAJ indicates that the changes resulting from the formation of the reservoir are remarkable. The filling of the reservoir reflects the flooding and isolation of areas with important resources for the provision of supplies for the subsistence of communities. The resulting reality is marked by the relocation of communities, the decline in the availability of natural resources, impairing food self-sufficiency and interfering in social and economic activities. As for the communities, 
they are left with readapting to the new life imposed to them and the establishment of new socio-environmental relations with the new, physically transformed environment.

The restoration of post-construction impacts has not been adequately implemented, especially with regard to the supply of water and energy, thus the expectations generated were not addressed. Therefore, it is necessary to provide electricity to the affected communities, since it can provide a larger set of subsistence alternatives and reduce dependence on forests and their resources.

\section{References}

AGOstinHO, A. A.; PELICICE, F. M.; GOMES, L. C. Dams and the fish fauna of the Neotropical region: impacts and management related to diversity and fisheries. Brazilian Journal of Biology, v. 68, n. 4 (supl.), p. 1119-1132, 2008.

BALDIN, N; MUNHOZ, E. M. B. Educação ambiental comunitária: uma experiência com a técnica de pesquisa SnowBall (Bola de Neve). Revista Eletrônica do Mestrado em Educação Ambiental, v. 27, ISSN 1517-1256, p. 46-60, 2011.

BARDIN, L. Análise de conteúdo. 4. ed. Lisboa: Edições 70, 2010. 225 p.

BERMANN, C. Impasses e controvérsias da hidreletricidade. Estudos Avançados, v. 21, n. 59, p. 139-153, 2007.

BORGES, R. S.; SILVA, V. P. Usinas Hidrelétricas o Brasil: a relação de afetividades dos atingidos com os lugares inundados pelos reservatórios. Caminhos da geografia, v. 12, n. 40, p. 222-231, 2011.

CAMPOS, K. F. S. Novas dinâmicas territoriais da Usina Hidrelétrica de Santo Antônio no vale do Jari: a desconstrução do uso do território e de produtos na RDS do Iratapuru/ AP. 2016. 108p. Dissertação (Mestrado Desenvolvimento Regional) - Universidade Federal do Amapá, Macapá, 2016.

CAMPOS, K. F. S., MENDONÇA, M. R.; CAMPOS, V. B. Território (des)conhecido nas águas do rio Jari: os efeitos da usina hidrelétrica Santo Antônio do Jari na comunidade tradicional do Iratapuru/AP. Interespaço, v.4, n. 12, p. 120-134, 2018.

CARVALHO, J. F. O setor elétrico e o dilema espaço público versus espaço privado. In: SAUER, I. L. et al. A reconstrução do setor elétrico brasileiro. Campo Grande: Editora UFMS \& Paz e Terra, 2003. p. 257-264.

CASTELLO, L; MACEDO, M. N. Large-scale degradation of the Amazon freshwater ecosystem. Global Change Biology, v. 22, p. 990-1007, 2016. Doi: https://doi.org/10.1111/gcb.13173 PMID: 26700407 
CESBE. CESBE S.A. ENGENHARIA E EMPREENDIMENTOS. Disponível em: < http://www. cesbe.com.br/obras/uhe-santo-antonio-do-jari/> Acesso: 20 fev. 2018.

Chandy, T., et al. Impacts of Hydropower Development on Rural Livelihood Sustainability in Sikkim, India: Community Perceptions. Mountain Research and Development, v. 32, n. 2, p. 117-125, 2012.

CRUZ, C. B.; SILVA, V. P. Grandes projetos de investimento: a construção de hidrelétricas e a criação de novos territórios. Sociedade $\&$ Natureza, v. 22, n.1, p. 181-190, 2010.

DERROSSO, G. S.; ICHIKAWA, E. Y. A construção de uma usina hidrelétrica e a reconfiguração das identidades dos ribeirinhos: um estudo em Salto Caxias, Paraná. Ambiente $\mathbb{\&}$ Sociedade, v. 17, n. 3, p. 97-114, 2014.

ECOLOGY BRASIL a. UHE Santo Antônio Jari: Plano Básico Ambiental - PBA, Rio de Janeiro, 2009.

ECOLOGY BRASIL b. UHE Santo Antônio Jari: Estudo de Impacto Ambiental EIA. Rio de Janeiro, 2009.

ECOLOGY BRASIL c. UHE Santo Antônio Jari: Relatório de Impacto Ambiental - RIMA. Rio de Janeiro, 2009.

ENERGIAS DE PORTUGAL a. Programa de monitoramento limnológico da UHE Santo Antônio do Jari. Relatório técnico consolidado referente ao monitoramento limnológico: fase pré-enchimento e pósenchimento (campanha de maio de 2017), 2017. Disponível em: http:// licenciamento.ibama.gov.br/Hidreletricas/Santo\%20Antonio\%20(Rio\%20Jari)/7\%C2\%BA\%20 Relat\%C3\%B3rio\%20Semestral/7\%C2\%BA\%20Relat\%C3\%B3rio\%20Semestral/ANEXOS/ Cap\%203.3.13\%20Limnologia/Anexo\%203.3.131_Relat\%C3\%B3rio_tecnico_consolidado_ ate_mai17/Relatorio_tecnico_consolidado_mai17.pdf. Acesso em: 28 jan. 2019.

ENERGIAS DE PORTUGAL b. Programa ambiental de monitoramento de processos erosivos da UHE SANTO ANTÔNIO DO JARI (Fase de Operação). Relatório Anual, 2017. Disponível em: http://licenciamento.ibama.gov.br/Hidreletricas/Santo\%20Antonio\%20(Rio\%20 Jari)/7\%C2\%BA\%20Relat\%C3\%B3rio\%20Semestral/7\%C2\%BA\%20Relat\%C3\%B3rio\%20 Semestral/ANEXOS/Cap\%203.3.3\%20-\%20Processos\%20Erosivos/Anexo\%203.3.3-1\%20-\%20 Monitoramento\%20Processos\%20Erosivos/1.\%20Relat\%C3\%B3rio\%20Processos\%20Erosivos. pdf. Acesso em: 10 jan 2019.

FEARNSIDE, P. M. Social impacts of Brazil's Tucuruí Dam. Environmental Management, v. 24, n. 4, p. 483-495, 1999. Doi: 10.1007/s002679900248.

. Environmental impacts of Brazil's Tucuruí Dam: unlearned lessons for hydroeletric development in Amazonia. Environmental Management, v. 27, n. 3, p. 377-396, 2001.

. Hidrelétricas na Amazônia: impactos ambientais e sociais na tomada de decisões sobre grandes obras. Manaus: Editora do INPA. 2015. 296 p. 
FONSECA, I. F. A construção de grandes barragens no Brasil, na China e na Índia: similitudes e peculiaridades dos processos de licenciamento ambiental em países emergentes. Texto para Discussão 1868. Rio de Janeiro: Instituto de Pesquisa Econômica Aplicada (IPEA), 2013.

GIL, A. C. Métodos e Técnicas de Pesquisa Social. 6. ed. São Paulo: Atlas, 2008. 216 p.

GREISSING, A. A região do Jarí, do extrativismo ao agronegócio: as contradições do desenvolvimento econômico na Amazônia florestal no exemplo do projeto Jarí. Revista de Estudos Universitários, v. 36, n. 3, p. 43-75, 2010.

IEA - INTERNATIONAL ENERGY AGENCY. Key world energy statistics. Paris: OCDE, 2017.

JERICÓ-DAMINELLO, C. et. al. Impactos econômicos da construção da hidrelétrica de São Luis do Tapajós: uma análise do provimento de serviços ecossitêmicos. Conservation Strategy Fund. 2016. 76 p.

JUNK, W. J.; MELLO, J. A. S. N. Impactos ecológicos das represas hidrelétricas na bacia amazônica brasileira. Estudos Avançados, v. 4, n. 8, p. 126-143, 1990.

KOIFMAN, S. Geração e transmissão da energia elétrica: impacto sobre os povos indígenas no Brasil. Cadernos de Saúde Pública, v. 17, n. 2, p. 413-423, 2001.

LEITE, A. C. P. C. Sustentabilidade na Amazônia: práticas econômicas de subsistência na comunidade de São Francisco do rio Iratapuru/AP. Revista Maré: memórias, imagens e saberes do campo, v.5, n.8, p. 35-44, 2015.

MANATUNGE, J.; NAKAYAMA, M.; PRIYADARSHANA, T. Environmental and social impacts of reservoirs: issues and mitigation. Oceans and Aquatic Ecosystems, v. 1, p. 212-255, 2008.

MARTINS, G. A.; THEÓPHILO, C. R. Metodologia da investigação científica para ciências sociais aplicadas. 2. Ed. São Paulo: Atlas, 2009. 247 p.

MME - MINISTÉRIO DE MINAS E ENERGIA. Secretaria de Planejamento e Desenvolvimento Energético; Empresa de Pesquisa Energética - EPE. Plano Nacional de Energia 2030. Brasília: MME; EPE, 2007.

MME-MINISTÉRIO DE MINAS E ENERGIA. Secretaria de Planejamento e Desenvolvimento Energético; Empresa de Pesquisa Energética EPE- Plano Decenal de Expansão de Energia 2020. Brasília: MME; EPE, 2011.

MME - MINISTÉRIO DE MINAS E ENERGIA. Secretaria de Planejamento e Desenvolvimento Energético; Empresa de Pesquisa Energética EPE- Plano Decenal de Expansão de Energia 2029. Brasília: MME; EPE, 2019.

OLIVEIRA, M. L. R. Reflexões sobre o uso do espaço em comunidades amazônicas: uma análise da comunidade extrativista do Iratapuru. Oikos: Revista Brasileira de Economia Doméstica, v. 
23, n. 1, p. 121-146, 2012.

PACHECO, J. Morte de peixes próximo a obra de hidrelétrica é investigada no Amapá. G1. -Amapá, Macapá, 01 julho 2015. Disponível em: http://g1.globo.com/ap/amapa/noticia/2015/07/ morte-de-peixes-proximo-obra-de-hidreletrica-e-investigada-no-amapa.html. Acesso em: 10 jan. 2019.

RICHTER, B. D. et al. Lost in development's shadow: The downstream human consequences of dams. Water Alternatives, v. 3, n. 2, p. 14-42, 2010.

SANTOS, E. S.; CUNHA, A. C. C.; CUNHA, H. F. A. Usina hidrelétrica na Amazônia e impactos socioeconômicos sobre os pescadores do município de Ferreira Gomes-Amapá. Ambiente $\mathbb{E}$ Sociedade, v.20, n. 4, p. 197-214, 2018.

SICILIANO, G.; URBAN, F. Equity-based natural resource allocation for infrastructure development: evidence from large hydropower dams in Africa and Asia. Ecological Economics, v. 134, p. 130-139, 2017.

SICILIANO, G. et. al. Hydropower, social priorities and the rural-urban development divide: The case of large dams in Cambodia. Energy Policy, v. 86, p. 273-285, 2015.

SILVA, C. R.; GOBBI, B. C.; SIMÃO, A. A. O uso da análise de conteúdo como uma ferramenta para a pesquisa qualitativa: descrição e aplicação do método. Organizações Rurais \& Agroindustriais, v. 7, n. 1, 2005.

SILVA, C. N.; LIMA, R. A. P.; SILVA, J. M. P. Uso do território e impactos das construções de hidroelétricas na bacia do rio Araguari (Amapá-Brasil). PRACS: Revista Eletrônica de Humanidades do Curso de Ciências Sociais da UNIFAP, v. 9, n. 2, p. 123-140, 2016.

SOITO, J. L. S.; FREITAS, M. A. V. Amazon and the expansion of hydropower in Brazil: Vulnerability, impacts and possibilities for adaptation to global climate change. Renewable and Sustainable Energy Reviews, v. 15, p. 3165-3177, 2011.

TULLOS, D.; TILT, B.; LIERMANN, C. R. Introduction to the special issue: Understanding and linking the biophysical, socioeconomic and geopolitical effects of dams. Journal of Environmental Management, v. 90, s. 3, p. S203-S207, 2009.

YANKSON, P. W. K. et. al. The livelihood challenges of resettled communities of the Bui Dam project in Ghana and the role of Chinese dam-builders. Development Policy Review. v. 36, p. 476-494, 2016. 
Maíria de Sousa Lopes

$\square$ mairia_lopes@hotmail.com

ORCiD: https://orcid.org/0000-0001-5354-7366
Submitted on: 05/04/2019

Accepted on: 12/02/2021

2021;24e:00683

\section{Daguinete Maria Chaves Brito}

$\square$ dagnete@uol.com.br

ORCiD: https://orcid.org/0000-0001-9856-4290

How to cite: LOPES, M. S.; BRITO, D. M. C. Socioenvironmental impacts of dams in the Jari Valley, Amapa, Brasil: community perceptions. Ambiente $\mathbb{\&}$ Sociedade. São Paulo, v. 24, p. 1-20, 2021. 


\title{
Impactos socioambientais ocasionados por hidrelétrica no Vale do Jari, Amapá, Brasil: percepções comunitárias
}

\author{
Maíria de Sousa Lopes \\ Daguinete Maria Chaves Brito
}

São Paulo. Vol. 24, 2021

Artigo Original
Resumo: A expansão do setor elétrico brasileiro está pautada na construção de novas hidrelétricas. No entanto, esses empreendimentos geram diversos impactos, especialmente sobre as comunidades ribeirinhas. Assim, este estudo examinou as percepções das comunidades locais sobre os impactos socioeconômicos e ambientais da hidrelétrica Santo Antônio do Jari, no Amapá. Os dados foram obtidos mediante aplicação de formulários, usando o método de seleção bola de neve. Para analisar a percepção utilizou-se a análise de conteúdo de Bardin. A pesquisa revelou que, antes da implantação da hidrelétrica, as comunidades possuíam um vínculo muito intimista com o território e a natureza, de modo que as percepções mais evidentes das comunidades incluem os impactos ambientais, realocação, mudanças nos meios de subsistência e acesso a recursos naturais, importantes para a manutenção dessas comunidades.

Palavras-chave: Alterações socioambientais; Comunidades ribeirinhas; Santo Antônio do Jari.

Como citar: LOPES, M. S.; BRITO, D. M. C. Impactos socioambientais ocasionados por hidrelétrica no Vale do Jari, Amapá, Brasil: percepções comunitárias. Ambiente \& Sociedade. São Paulo, v. 24, p. 1-20, 2021.

DOI: http://dx.doi.org/10.1590/1809-4422asoc20190068r3vu2021L2AO 


\title{
Impactos Socioambientales ocasionados por hidroeléctrica en el Valle del Jari, Amapá, Brasil: percepciones comunitarias
}

\author{
Maíria de Sousa Lopes \\ Daguinete Maria Chaves Brito
}

São Paulo. Vol. 24, 2021

Artículo original
Resumen: La expansión del sector eléctrico brasileño está basada en la construcción de nuevas hidroeléctricas. Sin embargo, estos emprendimientos generan diversos impactos, especialmente sobre las comunidades ribereñas. Así, este estudio examinó las percepciones de las comunidades locales sobre los impactos socioeconómicos y ambientales de la hidroeléctrica Santo Antônio do Jari, en Amapá. Los datos se obtuvieron mediante la aplicación de formularios, utilizando el método "muestreo de bola de nieve". Para analizar la percepción se utilizó el análisis de contenido de Bardin. La investigación reveló que, antes de la implantación de la hidroeléctrica, las comunidades tenían un vínculo muy íntimo con el territorio y la naturaleza, de modo que las percepciones más evidentes de las comunidades incluyen los impactos ambientales, reubicación, cambios en los medios de subsistencia y acceso a recursos naturales, importantes para el mantenimiento de esas comunidades.

Palabras-clave: Cambios socioambientales, comunidad ribereña, Santo Antônio do Jari.

Como citar: LOPES, M. S.; BRITO, D. M. C. Impactos Socioambientales ocasionados por hidroeléctrica en el Valle del Jari, Amapá, Brasil: percepciones comunitarias. Ambiente $\&$ Sociedade. São Paulo, v. 24, p. 1-20, 2021.

DOI: http://dx.doi.org/10.1590/1809-4422asoc20190068r3vu2021L2AO 